\title{
Physical mapping of rDNA genes corroborates allopolyploid origin in apomictic Brachiaria brizantha
}

\author{
Stephan Nielen · Lucas M. Almeida • \\ Vera T. C. Carneiro • Ana Claudia G. Araujo
}

Received: 1 June 2009/ Accepted: 26 November 2009/Published online: 15 December 2009

(C) Springer-Verlag 2009

\begin{abstract}
Brachiaria (Trin.) Griseb belongs to the family Poaceae, and within the genus, apomixis or sexuality is present in different accessions of the same species. The majority of Brachiaria species are polyploid and apomictic, making strategies for crop improvement by breeding very intricate. In spite of the high frequency of apomictic polyploids, the relationship of polyploidy and hybridization with apomixis in Brachiaria is still unclear. Further analysis requires detailed knowledge regarding the genomic composition of the polyploids. The present work introduces the use of fluorescent in situ hybridization (FISH) into cytogenetic analysis of Brachiaria. Physical mapping of heterologous rDNA sequences, associated with conventional karyotyping of the $B$. brizantha diploid sexual (BRA 002747) and the tetraploid apomictic (BRA000591) accessions, provided evidence of the latter being of allopolyploid origin. Based on our results and on previous knowledge on apomixis in B. brizantha, we suggest that the origin of apomixis was probably a consequence of hybridization.
\end{abstract}

Keywords Allopolyploid - Apomixis - Chromosomes · Cytogenetics · FISH · Hybridization

Communicated by Anna Koltunow.

S. Nielen · L. M. Almeida · V. T. C. Carneiro ·

A. C. G. Araujo ( $\square)$

Embrapa Genetic Resources and Biotechnology,

Parque Estação Biológica (PqEB), Final W5 Norte,

P.O.Box 02354, Brasília, DF 70770-900, Brazil

e-mail: guerra@cenargen.embrapa.br

\section{Introduction}

Species of the genus Brachiaria (Trin.) Griseb. (Poaceae) are important forage grasses in tropical and subtropical countries. In Brazil, the cultivated pasture area comprises around 115 million hectares (Karia et al. 2006), forming the main basis for cattle production. The majority of this area, from 50 to 70 million hectares, is cultivated with Brachiaria.

Analysis of accessions in the Brachiaria collection established at the International Center for Tropical Agriculture (CIAT), Colombia and duplicated at Embrapa, Brazil, indicated an evident prevalence of polyploids. The wide predominance of tetraploids is based on the basic chromosome number $x=9$ (Sotomayor-Ríos et al. 1968; Christopher and Abrahan 1976; Thompson and Estes 1986; Basappa et al. 1987; Dujardin 1979; Valle and Glienke 1991; Valle and Savidan 1996; Bernini 1997; Penteado et al. 2000; Bernini and Marin-Morales 2001; MendesBonato et al. 2002a; Risso-Pascotto et al. 2003, Utsunomiya et al. 2005). Also, it is evident that polyploidy in the genus is associated with apomixis (Valle and Savidan 1996), a natural mechanism of plant reproduction that results in the formation of seeds asexually, that retains the maternal genotype in the progeny (Hanna and Bashaw 1987, Asker and Jerling 1992; Nogler 1984). No diploid accession of this collection presented apomixis, and only one tetraploid $B$. humidicola was characterized as sexual (Valle et al. 2008).

In the most cultivated species in Brazil, $B$. brizantha, a polyploidy series, is present with reports of diploid, tetra, penta, and hexaploid accessions (Valle and Glienke 1991; Penteado et al. 2000; Mendes-Bonato et al. 2002b; Risso-Pascotto et al. 2003). Only one accession among 275 is a diploid sexual, while the remaining are polyploid 
apomicts (Carnahan and Hill 1961; Valle and Glienke 1991). Despite the frequent occurrence of polyploidy in Brachiaria, the putative association of polyploidy and hybridization with apomixis in the genus is still unclear.

Hybridization is considered, since Ernst's work (1918, in Tucker and Koltunow 2009), as an important factor in the evolution of apomixis, because all natural apomicts are polyploid and highly heterozygous. Carman (1997, 2001, 2007) suggested that apomixis might result from the asynchronous expression of the genes involved in female reproduction in hybrids of two sexual-related ancestors. More recent analyses showing that the character is under the control of few loci suggest that apomixis may be a consequence of mutation in alleles of genes controlling sexuality or a consequence of epigenetic changes in gene regulation. Therefore, apomixis might develop through different pathways from ancestors with sexual modes of reproduction (reviewed by Koltunow and Grossniklaus 2003; Tucker and Koltunow 2009).

Apomixis segregation analysis in Brachiaria showed that this character is under the control of a single dominant locus, whereas sexuality is recessive; the suggested genotype for tetraploid apomicts in Brachiaria is Aaaa and for diploid sexuals, $a a$ (Valle et al. 1994; Miles and Escandon 1997). The absence of the apomictic character in induced tetraploid plants of diploid sexual B. brizantha and B. ruziziensis (Swenne et al. 1981; Gobbe et al. 1981, 1982; Araujo et al. 2005) corroborates the hypothesis that apomixis in the genus depends mainly on different gene profiles $(A)$ which probably originated through hybridization and/or mutation. Additionally, analysis of meiotic behavior indicated the presence of more than one genome within pentaploid accessions of B. brizantha (Mendes 2004; Mendes et al. 2006), in B. ruziziensis (Risso-Pascotto et al. 2005), and in B. humidicola (Boldrini et al. 2006).

The major objective of the present work was a cytogenetic analysis of $B$. brizantha diploid sexual (BRA 002747) and tetraploid apomictic accessions (BRA000591) aimed at elucidating the origin of polyploidy in the apomictic accession. Therefore, as a new approach in Brachiaria chromosome analysis, we have introduced the use of fluorescent in situ hybridization (FISH) for physical mapping of heterologous 5S- and 18S-5.8S-25S rDNA sequences. The rDNA loci have been shown previously to provide useful chromosome markers to differentiate genomes in allotetraploids, such as Brassica juncea (Maluszynska and Hasterok 2005) or Arachis hypogaea (Seijo et al. 2004). In particular, the number and localization of 5S rDNA loci are often a distinguishing feature between even closely related genomes, as has been shown by ecotype-specific polymorphisms in Arabidopsis thaliana (Fransz et al. 1998). Here, we demonstrate that in situ hybridization of rDNA probes in combination with conventional karyotyping was effective in determining the allopolyploid origin of the apomictic $B$. brizantha accession. Based on our findings and on the previously published data on B. brizantha as specified earlier, we suggest that the probable origin of apomixis was through hybridization.

\section{Materials and methods}

\section{Plant material}

Plants of $B$. brizantha diploid $(2 n=2 x=18)$ sexual accession BRA-002747, tetraploid $(2 n=4 x=36)$, apomictic accession BRA-000591 (cv. Marandu) were maintained in the experimental field at Embrapa Genetic Resources and Biotechnology, Brasília-DF, Brazil. Stolons of these plants were transferred to plastic bags containing sterile soil and kept in the greenhouse for 2-3 weeks.

\section{Chromosome preparation}

After this time, root tips of $5 \mathrm{~mm}$ length were isolated from the germinating roots of at least five plants around 8:30 am, when meristematic activity was high. The root tips were washed in distilled water and treated with $0.002 \mathrm{M}$ 8 -hydroxyquinoline for $1 \mathrm{~h}$ at room temperature and $2 \mathrm{~h}$ at $4^{\circ} \mathrm{C}$. The material was fixed in freshly prepared 3:1 ethanol-glacial acetic acid for $12 \mathrm{~h}$ and maintained in $70 \%$ ethanol at $4^{\circ} \mathrm{C}$. Samples were washed in $1 \times$ enzyme buffer (4 $\mathrm{mM}$ citric acid, $6 \mathrm{mM}$ sodium citrate, $\mathrm{pH} 4.8$ ), and incubated in an enzyme mixture consisting of $11.9 \%$ pectinase (Sigma P2401 from Rhyzopus sp.) and 7\% cellulase (Sigma C1184 from Aspergillus niger) at $37^{\circ} \mathrm{C}$ for $3 \mathrm{~h}$. The roots tips were subsequently washed two times in $1 \times$ enzyme buffer for 15 min each. Root meristems were dissected on histological slides in $45 \%$ acetic acid, dried, and treated by Feulgen reaction (Feulgen and Rossenbeck $1924)$ or incubated with Chromomycin $\mathrm{A}_{3}\left(\mathrm{CMA}_{3}\right)$ or $4^{\prime}, 6$ diamidino-2-phenylindole (DAPI). For FISH analysis, excised meristems were squashed in a drop of $45 \%$ acetic acid. Cover slips were removed after freezing the slides in liquid nitrogen. The preparations were stained for $30 \mathrm{~min}$ with $2 \mu \mathrm{g} / \mathrm{ml}$ DAPI to enable quality testing using fluorescence microscopy.

\section{Morphological analyses}

Metaphase chromosomes from nine cells from each accession were analyzed. Based on average length of the chromosomes, the arms ratio (long arm/short arm of individual chromosomes), the position of the centromere, the presence of satellites, and the karyotypes of both accessions of $B$. brizantha were constructed. 
In situ hybridization

Probes were labeled either with digoxigenin-11-dUTP or biotin-11-dUTP (Roche) by random primed labeling. Probes used were pTa71 containing the 18S-5.8S-25S rDNA genes from Triticum aestivum (Gerlach and Bedbrook 1979) and pTA794, which has the complete 5S rDNA gene of T. aestivum (Gerlach and Dyer 1980). Pretreatment, hybridization, washing, and detection procedures essentially followed protocols of Schwarzacher and Heslop-Harrison (2000). Denatured DNA probes (100 ng/ml) were mixed in a hybridization solution containing $50 \%$ (v/v) formamide, $10 \%(\mathrm{w} / \mathrm{v})$ dextran sulfate, $0.125 \mathrm{mM}$ EDTA, $0.125 \%(\mathrm{w} / \mathrm{v})$ SDS, and $1 \mu \mathrm{g}$ of salmon sperm DNA. The chromosomes and DNA were denatured together by incubating the slides with hybridization/probe mix in a humid chamber at $78-80^{\circ} \mathrm{C}$ for $10 \mathrm{~min}$, floating in a heated water bath. Subsequently, the temperature in the chamber was slowly brought to $37^{\circ} \mathrm{C}$, and the slides were incubated for $16 \mathrm{~h}$ at this temperature. Hybridization sites were detected by sheep anti-digoxigenin conjugated to fluorescein isothiocyanate (anti-dig-FITC; green fluorescence) and Cy3-streptavidin (red fluorescence). FITC signals were amplified using anti-sheep antibody conjugated to fluorescein (Vector Laboratories). Chromosomes were counterstained with DAPI. Slides were observed with Zeiss Axiophot epifluorescence microscope using appropriate filters. Microphotographs were taken on Kodak Ultra ISO 400 color print film, digitalized and edited using only Adobe Photoshop functions (brightness, cropping, overlay), which affect the whole image equally.

\section{Results}

A general karyogram based on $\mathrm{CMA}_{3}$ and DAPI staining of somatic metaphase chromosomes of the two accessions of $B$. brizantha, the diploid sexual and the tetraploid apomictic is shown in Fig. 1. Chromosomes are paired and ordered according to their size. This analysis confirmed the presence of 18 and 36 chromosomes in the diploid sexual and tetraploid apomictic, respectively, with a basic chromosome number of $x=9$. A more detailed picture was achieved when analyzing Feulgen-stained chromosomes with regard to the length of the chromosomes $(\mu \mathrm{m})$, the arms ratio (long arm/short arm of individual chromosomes), and the centromere position. Results of this analysis are shown in Tables 1 and 2, and represented as ideograms in Fig. 2.

In the diploid accession, five pairs of homologous chromosomes were submetacentric (SM), three metacentric (M) and only one subtelocentric (ST), following the classification of Levan et al. (1964) (Figs. 1, 2). The shortest pair of chromosomes was $2.4 \mu \mathrm{m}$ long, designated pair IX, and the ratio of the short to long arm length in this pair was 1.38. The longest pair (I) of this accession was $5.15 \mu \mathrm{m}$ long, and the ratio of the arms was 4.13 in this pair (Table 1). One pair of satellite chromosomes could be identified in chromosome pair VIII. The satellites were easier to identify after in situ hybridization of the $18 \mathrm{~S}$ 5.8S-25S rDNA probe, as delineated later (Fig. 5b). Almost all pairs of homologous chromosomes in the tetraploid accession showed the centromere in the median region, except for the pairs III and XIV, which were submetacentric (SM; Table 2). The shortest pair was $2.2 \mu \mathrm{m}$ long, and the longest was $5.6 \mu \mathrm{m}$. Chromosome pair VIII showed a secondary constriction and a satellite, which was more clearly visible after DAPI staining (Fig. 5a). The average length in the pair I of the diploid accession $(5.15 \mu \mathrm{m})$ was similar to those determined in pairs I and II of the tetraploid accessions (5.6 and $5.2 \mu \mathrm{m})$. Similarly, pair II $(4.85 \mu \mathrm{m})$ was similar to pairs III and IV (4.85 and $4.75 \mu \mathrm{m})$, pair III $(4.55 \mu \mathrm{m})$ to pairs V and VI (4.55 and $4.3 \mu \mathrm{m}$ ) and so forth up to the pair IX.

The localization of ribosomal genes through FISH using heterologous sequences for $5 \mathrm{~S}$ and $18 \mathrm{~S}-5.8 \mathrm{~S}-25 \mathrm{~S}$ rDNA as probes is shown in Figs. 3-5. In the diploid accession (Fig. 3a, b), the 5S rDNA probe was observed in the interstitial region of only one pair of chromosomes. One large 18S-5.8S-25S locus was detected mainly on the satellites of the chromosome pair, which displays a secondary constriction (chromosome pair VIII in Fig. 1,2). This site
Fig. 1 Brachiaria brizantha metaphase chromosomes. a Diploid sexual BRA-002747 ( $\mathrm{CMA}_{3}$ staining). b Tetraploid apomictic BRA-000591 (DAPI staining). Scale bar $3 \mu \mathrm{m}$
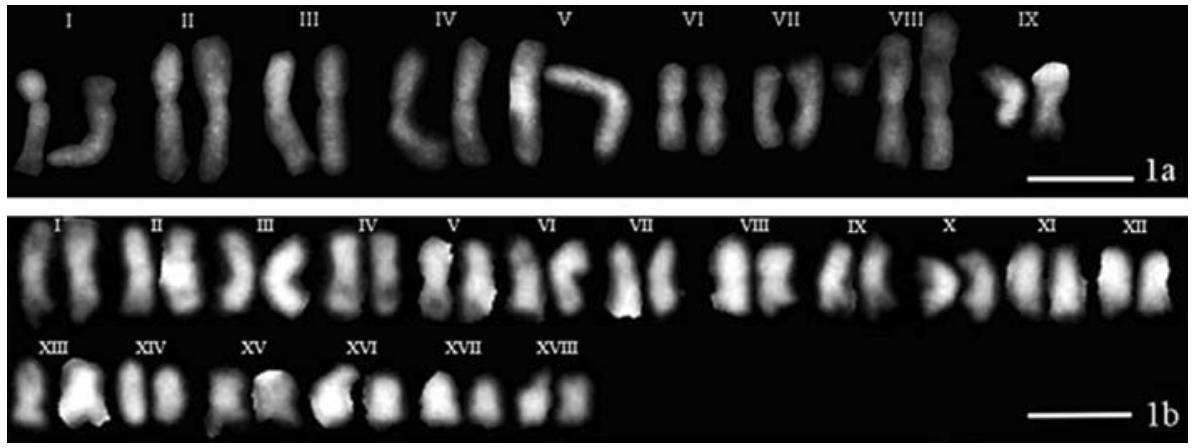
Table 1 Diploid sexual accession of $B$. brizantha BRA002747 $(2 n=2 x=18)$

\begin{tabular}{|c|c|c|c|c|c|c|c|c|c|c|c|c|c|c|c|c|c|c|}
\hline \multirow{2}{*}{$\begin{array}{l}\text { Pair of chromosomes } \\
\text { Chromosomes }\end{array}$} & \multicolumn{2}{|l|}{ I } & \multicolumn{2}{|l|}{ II } & \multicolumn{2}{|l|}{ III } & \multicolumn{2}{|l|}{ IV } & \multicolumn{2}{|l|}{ V } & \multicolumn{2}{|l|}{ VI } & \multicolumn{2}{|l|}{ VII } & \multicolumn{2}{|l|}{ VIII } & \multicolumn{2}{|l|}{ IX } \\
\hline & 1 & 2 & 1 & 2 & 1 & 2 & 1 & 2 & 1 & 2 & 1 & 2 & 1 & 2 & 1 & 2 & 1 & 2 \\
\hline Cell 1 & 6.0 & 6.0 & 5.8 & 5.5 & 5.7 & 5.7 & 5.5 & 5.5 & 5.1 & 5.1 & 4.1 & 4.1 & 3.8 & 3.8 & 3.7 & 3.7 & 3.4 & 3.3 \\
\hline Cell 2 & 4.8 & 4.8 & 4.7 & 4.7 & 4.7 & 4.7 & 4.1 & 4.1 & 3.8 & 3.8 & 3.6 & 3.5 & 3.5 & 3.5 & 3.4 & 3.3 & 2.9 & 2.6 \\
\hline Cell 3 & 5.1 & 5.1 & 5.1 & 5.1 & 4.7 & 4.7 & 4.5 & 4.5 & 3.9 & 3.9 & 3.6 & 3.6 & 3.5 & 3.5 & 3.3 & 3.3 & 2.6 & 2.4 \\
\hline Cell 4 & 5.5 & 5.5 & 5.5 & 5.5 & 4.9 & 4.9 & 4.5 & 4.5 & 4.1 & 3.8 & 3.7 & 3.7 & 3.4 & 3.4 & 3.0 & 2.8 & 2.6 & 2.4 \\
\hline Cell 5 & 4.6 & 4.5 & 4.3 & 4.1 & 4.1 & 4.1 & 4.1 & 3.8 & 3.6 & 3.4 & 2.6 & 2.5 & 2.6 & 2.4 & 2.2 & 2.2 & 1.9 & 1.7 \\
\hline Cell 6 & 5.3 & 5.3 & 4.2 & 4.2 & 4.1 & 3.9 & 3.8 & 3.6 & 3.8 & 3.5 & 3.5 & 3.5 & 3.2 & 2.6 & 2.6 & 2.6 & 2.0 & 2.0 \\
\hline Cell 7 & 4.4 & 4.1 & 4.1 & 4.1 & 3.8 & 3.8 & 3.5 & 3.5 & 3.5 & 3.2 & 3.0 & 3.0 & 2.9 & 2.9 & 2.6 & 2.5 & 2.3 & 2.3 \\
\hline Cell 8 & 5.8 & 5.8 & 5.1 & 5.1 & 5.2 & 5.1 & 4.6 & 4.6 & 4.1 & 4.1 & 3.6 & 3.6 & 3.4 & 3.2 & 3.3 & 3.0 & 2.7 & 2.4 \\
\hline Cell 9 & 5.5 & 5.2 & 4.6 & 4.6 & 4.3 & 4.3 & 4.3 & 4.3 & 3.9 & 3.9 & 3.6 & 3.6 & 3.6 & 3.6 & 3.2 & 3.0 & 2.4 & 2.2 \\
\hline $\bar{X}$ & 5.20 & 5.10 & 4.80 & 4.70 & 4.60 & 4.50 & 4.30 & 4.20 & 3.90 & 3.80 & 3.40 & 3.40 & 3.30 & 3.20 & 3.00 & 2.90 & 2.50 & 2.30 \\
\hline$\sigma$ & 0.44 & 0.46 & 0.44 & 0.53 & 0.46 & 0.58 & 0.53 & 0.58 & 0.20 & 0.27 & 0.41 & 0.34 & 0.31 & 0.45 & 0.45 & 0.43 & 0.43 & 0.41 \\
\hline Length $\bar{X}$ of the pair & 5.15 & & 4.75 & & 4.55 & & 4.25 & & 3.85 & & 3.40 & & 3.25 & & 2.95 & & 2.40 & \\
\hline Arms length ratio & 4.13 & & 1.87 & & 2.33 & & 2.00 & & 1.11 & & 1.96 & & 2.50 & & 1.02 & & 1.38 & \\
\hline Centromere position & ST & & SM & & SM & & SM & & M & & SM & & SM & & M & & M & \\
\hline
\end{tabular}

Metaphase cells from root meristems showing the length of the chromosomes $(\mu \mathrm{m})$, the arms length ratio (long arm/short arm of individual chromosomes), and the centromere position

$M$ metacentric, $S M$ submetacentric, $S T$ subtelocentric

corresponds to the nucleolar-organizing region (NOR). In the tetraploid accession, three pairs of $5 \mathrm{~S}$ rDNA sites were detected using the $5 \mathrm{~S}$ rDNA probe (Fig. $4 \mathrm{~b}$, d), whereas the 18S-5.8S-25S rDNA sequence was detected in two pairs of chromosomes (Figs. 4d, 5b). Figure 5b clearly shows that there is only one pair with active sites of $18 \mathrm{~S}-5.8 \mathrm{~S}-25 \mathrm{~S}$ rDNA. The other locus is on the terminal region of a chromosome pair lacking satellites, which is inactive. The 18S-5.8S-25S rDNA and the 5S rDNA sites of the diploid accessions were also mapped in the ideograms (Fig. 2).

\section{Discussion}

This work confirms that combining conventional karyotyping and fluorescent in situ hybridization (FISH) facilitates ideogram construction and interpretation of origins of polyploidy in Brachiaria accessions.

In the tetraploid apomictic accession, the ratio of the length of the arms was very similar for all pairs, suggesting structural stability. Metacentric chromosomes were prevalent in this accession as well as found in other tetraploid accessions (Bernini and Marin-Morales 2001); however, chromosomes were longer than those previously described. On the other hand, the majority of the chromosomes of the diploid accession analyzed were SM and longer than those described by Bernini and Marin-Morales (2001) as being metacentric. This is an indication of some phylogenetic distance between this accession and other diploids. It could also be a result of bulky chromosome structural alterations in this accession. The presence of secondary constrictions in chromosome pair VIII was also described for the diploid sexual accession R134 of B. ruziziensis (Bernini and Marin-Morales 2001), suggesting the conservation of this cytogenetic character along species differentiation. A relationship in the length of the chromosomes of the diploid and the tetraploid accession was observed but with different centromere positions.

Further evidence indicating the allotetraploid origin of the $B$. brizantha apomictic accession BRA000591 was provided using FISH with $5 \mathrm{~S}$ and $18 \mathrm{~S}-5.8 \mathrm{~S}-25 \mathrm{~S}$ rDNA probes, thus corroborating previous suggestion of allopolyploidy (Mendes-Bonato et al. 2002a, Mendes et al. 2006). The most striking difference between the two accessions is the presence of only one locus of 5S rDNA in the diploid and three loci in the tetraploid accession. This was verified in metaphase as well as in interphase nuclei (data not shown). In the case of tetraploidization through chromosome doubling, two loci would have been expected. Furthermore, hybridization of the 18S-5.8S-25S rDNA probe identified one active NOR site in the diploid accession and two loci in the tetraploid, but only one active on a chromosome pair with secondary constrictions. This indicates a phenomenon described as nucleolar dominance. According to this phenomenon, hybrids or allopolyploids develop nucleoli on chromosomes of only one of the two parents (for review see Pikaard 2000).

The establishment of a FISH protocol for localization of multiple rDNA sequences provides a novel approach for viewing genomic organization and chromosome 
Table 2 Tetraploid apomictic accession of B. brizantha BRA000591 $(2 n=4 x=36)$

\begin{tabular}{|c|c|c|c|c|c|c|c|c|c|c|c|c|c|c|c|c|c|c|}
\hline \multirow{2}{*}{$\begin{array}{l}\text { Pair of chromosomes } \\
\text { Chromosomes }\end{array}$} & \multicolumn{2}{|l|}{ I } & \multicolumn{2}{|l|}{ II } & \multicolumn{2}{|l|}{ III } & \multicolumn{2}{|l|}{ IV } & \multicolumn{2}{|l|}{$\mathrm{V}$} & \multicolumn{2}{|l|}{ VI } & \multicolumn{2}{|l|}{ VII } & \multicolumn{2}{|l|}{ VIII } & \multicolumn{2}{|l|}{ IX } \\
\hline & 1 & 2 & 1 & 2 & 1 & 2 & 1 & 2 & 1 & 2 & 1 & 2 & 1 & 2 & 1 & 2 & 1 & 2 \\
\hline Cell 1 & 6.1 & 6.1 & 3.9 & 3.7 & 3.4 & 3.4 & 3.4 & 3.3 & 3.4 & 3.2 & 3.1 & 3.0 & 3.0 & 2.9 & 3.0 & 2.9 & 2.9 & 2.8 \\
\hline Cell 2 & 4.2 & 4.1 & 4.1 & 4.0 & 3.9 & 3.8 & 3.7 & 3.6 & 3.5 & 3.5 & 3.4 & 3.2 & 3.2 & 3.2 & 3.1 & 3.0 & 2.9 & 2.9 \\
\hline Cell 3 & 5.5 & 5.3 & 5.1 & 4.8 & 4.7 & 4.6 & 4.6 & 4.6 & 4.4 & 4.4 & 4.3 & 4.1 & 3.7 & 3.5 & 3.4 & 3.3 & 3.5 & 3.3 \\
\hline Cell 4 & 6.3 & 6.2 & 6.1 & 5.9 & 5.9 & 5.5 & 5.5 & 5.2 & 5.4 & 5.2 & 5.2 & 5.1 & 4.7 & 4.7 & 4.6 & 4.5 & 4.6 & 4.6 \\
\hline Cell 5 & 5.9 & ND & 5.6 & 5.3 & 5.3 & 5.2 & 5.3 & 5.2 & 4.9 & 4.7 & 4.8 & 4.5 & 4.5 & 4.4 & 3.5 & 3.2 & 3.0 & 3.3 \\
\hline Cell 6 & 5.8 & 5.7 & 5.6 & 5.3 & 5.5 & 5.5 & 5.3 & 5.3 & 5.3 & 5.3 & 5.0 & 4.8 & 4.8 & 4.6 & 4.6 & 4.4 & 4.1 & 4.1 \\
\hline Cell 7 & 6.0 & 6.0 & 6.0 & 5.8 & 5.3 & 5.3 & 5.3 & 5.0 & 5.1 & 5.1 & 4.8 & 4.4 & 4.5 & 4.3 & 4.5 & 4.2 & 4.1 & 4.1 \\
\hline Cell 8 & ND & ND & 6.0 & 5.9 & 5.8 & 5.5 & 5.8 & 5.5 & 5.5 & 5.4 & 5.5 & 5.2 & 5.0 & 4.7 & 4.8 & 4.3 & 4.7 & 4.7 \\
\hline Cell 9 & 6.2 & ND & 5.8 & 5.5 & 4.8 & ND & 4.6 & 4.6 & 4.4 & 4.3 & 4.3 & 4.0 & 3.8 & 3.8 & 3.8 & 3.6 & 3.8 & 3.6 \\
\hline$\overline{\mathrm{X}}$ & 5.70 & 5.50 & 5.30 & 5.10 & 4.90 & 4.80 & 4.80 & 4.70 & 4.60 & 4.50 & 4.40 & 4.20 & 4.10 & 4.00 & 3.80 & 3.70 & 3.70 & 3.70 \\
\hline$\sigma$ & 0.63 & 0.72 & 0.78 & 0.76 & 0.80 & 0.78 & 0.78 & 0.72 & 0.74 & 0.75 & 0.73 & 0.72 & 0.68 & 0.64 & 0.61 & 0.68 & 0.63 & 0.68 \\
\hline Length $\bar{X}$ of the pair & 5.60 & & 5.20 & & 4.85 & & 4.75 & & 4.55 & & 4.30 & & 4.05 & & 3.75 & & 3.70 & \\
\hline Arms length ratio & 1.60 & & 1.00 & & 1.97 & & 1.25 & & 1.21 & & 1.56 & & 1.65 & & 1.25 & & 1.66 & \\
\hline Centromere position & M & & M & & SM & & M & & M & & M & & M & & M & & M & \\
\hline Pair of chromosomes & $\mathrm{X}$ & & XI & & XII & & XIII & & XIV & & $\mathrm{XV}$ & & XVI & & XVII & & XVIII & \\
\hline Chromosomes & 1 & 2 & 1 & 2 & 1 & 2 & 1 & 2 & 1 & 2 & 1 & 2 & 1 & 2 & 1 & 2 & 1 & 2 \\
\hline Cell 1 & 2.8 & 2.7 & 2.5 & 2.5 & 2.5 & 2.5 & 2.6 & 2.5 & 2.4 & 2.3 & 2.3 & 2.3 & 2.3 & 2.3 & 2.0 & 2.0 & 2.0 & 1.9 \\
\hline Cell 2 & 2.9 & 2.9 & 2.7 & 2.6 & 2.6 & 2.6 & 2.5 & 2.5 & 2.5 & 2.5 & 2.6 & 2.3 & 2.3 & 2.3 & 2.2 & 2.2 & 2.0 & 2.0 \\
\hline Cell 3 & 3.7 & 3.3 & 3.2 & 3.1 & 3.2 & 3.1 & 3.1 & 3.0 & 3.0 & 3.0 & 2.8 & 2.5 & 2.3 & 2.3 & 2.3 & 2.2 & 2.3 & 2.2 \\
\hline Cell 4 & 4.3 & 4.0 & 4.1 & 3.9 & 4.1 & 3.7 & 4.0 & 3.8 & 3.4 & 3.3 & 3.3 & 3.3 & 3.3 & 3.2 & 2.7 & 2.6 & 2.5 & 2.3 \\
\hline Cell 5 & 3.1 & 3.0 & 3.0 & 3.0 & 3.1 & 2.9 & 2.9 & 2.8 & 2.8 & 2.7 & 2.8 & 2.7 & 2.9 & 2.5 & 2.3 & 2.3 & 2.2 & 2.1 \\
\hline Cell 6 & 4.1 & 3.9 & 3.7 & 3.7 & 3.8 & 3.5 & 3.6 & 3.3 & 3.4 & 2.4 & 3.0 & 3.0 & 2.7 & 2.7 & 2.6 & 2.5 & 2.2 & 1.9 \\
\hline Cell 7 & 4.1 & 4.0 & 4.0 & 3.9 & 3.9 & 3.6 & 3.6 & 3.3 & 3.4 & 3.2 & 3.3 & 3.3 & 3.2 & 3.1 & 2.6 & 2.5 & ND & ND \\
\hline Cell 8 & 4.6 & 4.6 & 4.5 & 3.9 & 4.1 & 3.9 & 3.9 & 3.9 & 3.8 & ND & 3.6 & 3.4 & 3.3 & 3.2 & 3.0 & 2.9 & 2.4 & 2.1 \\
\hline Cell 9 & 3.7 & 3.7 & 3.7 & ND & 3.6 & 3.5 & 3.2 & 3.0 & 3.1 & 2.5 & 3.0 & 2.9 & 2.7 & 2.5 & 2.6 & 2.4 & 2.4 & 2.3 \\
\hline$\overline{\mathrm{X}}$ & 3.70 & 3.50 & 3.00 & 3.30 & 3.40 & 3.20 & 3.20 & 3.10 & 3.00 & 2.70 & 2.90 & 2.80 & 2.70 & 2.60 & 2.40 & 2.40 & 2.10 & 2.10 \\
\hline$\sigma$ & 0.63 & 0.59 & 0.70 & 0.55 & 0.50 & 0.44 & 0.51 & 0.47 & 0.44 & 0.39 & 0.38 & 0.40 & 0.40 & 0.37 & 0.29 & 0.24 & 0.22 & 0.15 \\
\hline Length $\bar{X}$ of the pair & 3.60 & & 3.30 & & 3.30 & & 3.15 & & 2.95 & & 2.85 & & 2.65 & & 2.40 & & 2.10 & \\
\hline Arms length ratio & 1.70 & & 1.00 & & 1.03 & & 1.06 & & 1.77 & & 1.03 & & 1.00 & & 1.36 & & 1.00 & \\
\hline Centromere position & M & & M & & $\mathrm{M}$ & & $\mathrm{M}$ & & SM & & M & & M & & M & & $\mathrm{M}$ & \\
\hline
\end{tabular}

$N D$ not determined, $M$ metacentric, $S M$ submetacentric, $S T$ subtelocentric

Fig. 2 B. brizantha metaphase chromosomes spread after

Feulgen reaction and ideograms. a Diploid sexual BRA-002747. b Tetraploid apomictic BRA000591. In the ideograms, sites of 5S rDNA are labeled green and those of $18 \mathrm{~S}-5.8 \mathrm{~S}-25 \mathrm{~S}$ rDNA red. The three 5S rDNA sites in BRA-000591 could not be assigned distinctly. Scale bar (micrographs) $6 \mu \mathrm{m}$ (a) and 20 $\mu \mathrm{m}$ (b); scale bar (ideograms) $2 \mu \mathrm{m}$

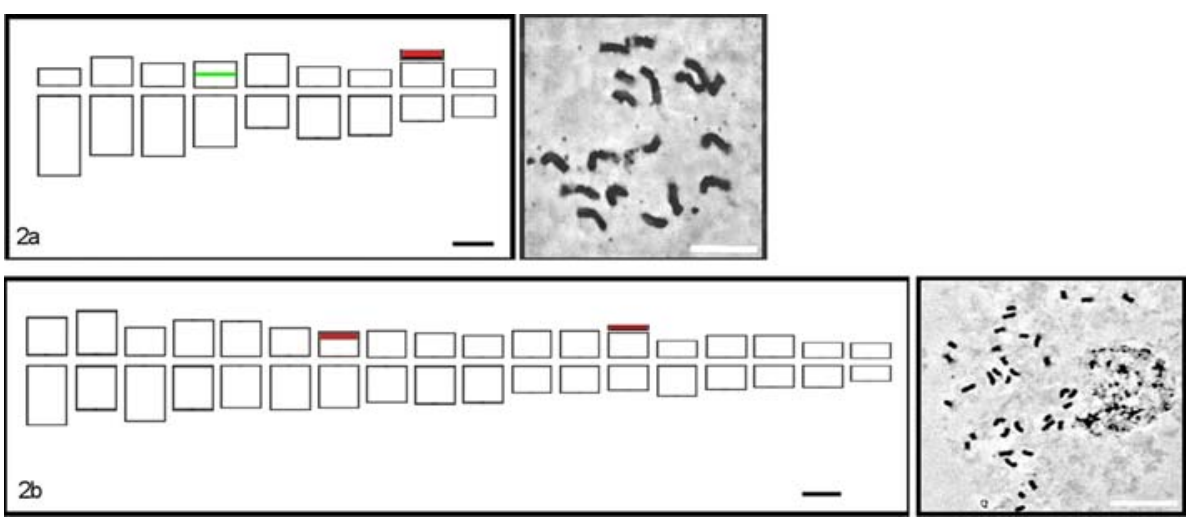



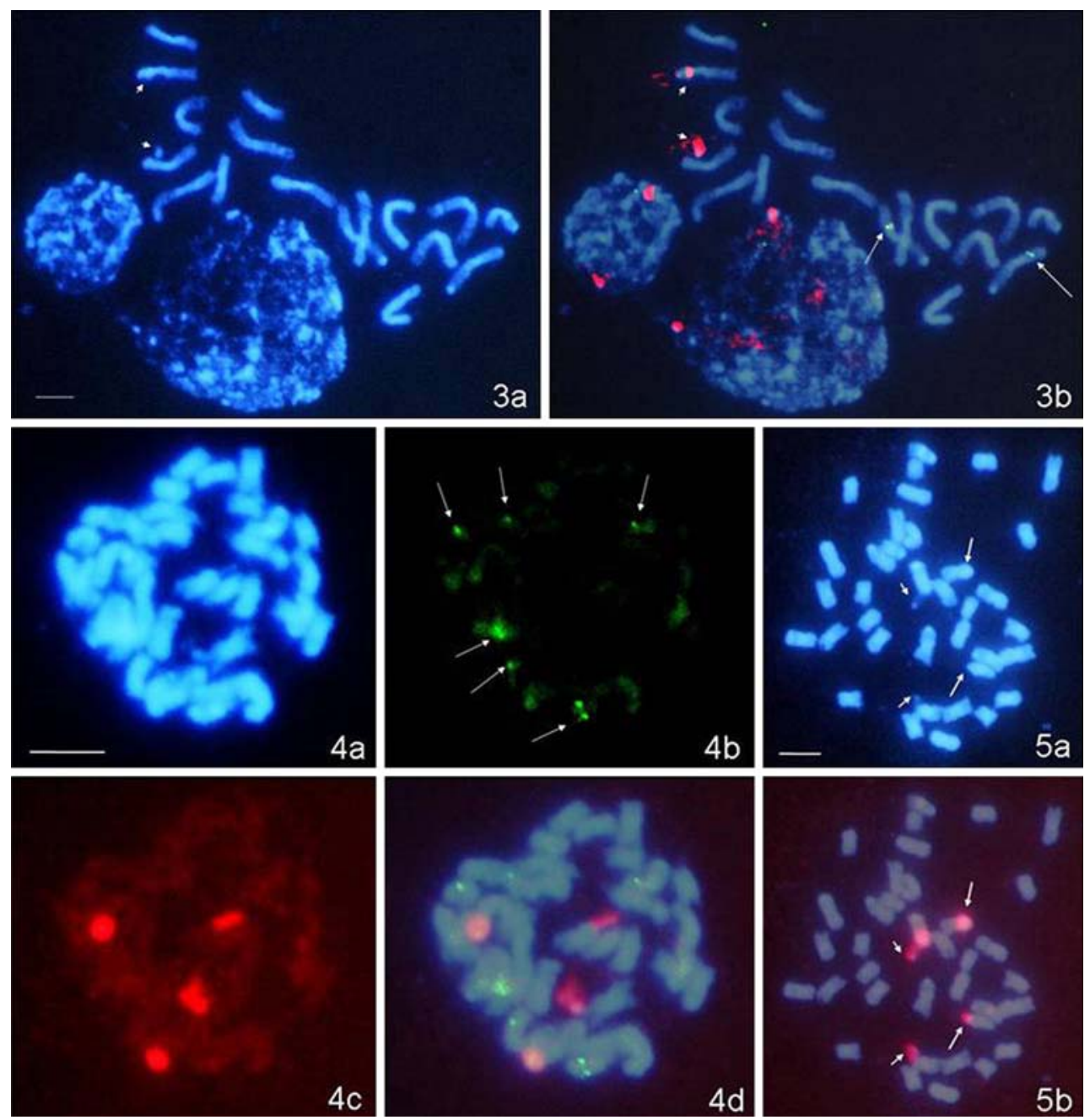

Figs. 3-5 Fluorescent in situ hybridization (FISH) in metaphase chromosomes of B. brizantha using 5S (green) and 18S-5.8S-25S (red) rDNA probes. 3 Diploid sexual BRA-002747; 3a DAPI staining; $3 \mathbf{b}$ detection of one pair of sites of 5S rDNA (arrows) and one pair of sites of 18S-5.8S-25S rDNA mainly on the satellite of another

structure in Brachiaria, also opening up new perspectives with regard to physical mapping of apomixis-related DNA sequences in the absence of large segregating populations and genetic polymorphisms yet unavailable for the genus.

Previous knowledge on $B$. brizantha suggests that apomixis expression depends on a different gene allele $(A)$ (Swenne et al. 1981; Gobbe et al. 1981, 1982; Araujo et al. 2005), single and dominant (Valle et al. 1994; Miles and Escandon 1997), the meiosis profile (Mendes 2004; RissoPascotto et al. 2005, Mendes-Bonato et al. 2006, Boldrini et al. 2006), and current results are strong evidence of allopolyploidization in apomicts. These data corroborate the hypothesis that the origin of apomixis in Brachiaria is through hybridization, as suggested for many other systems (Carman 1997, 2001, 2007). chromosome (arrowhead) after double hybridization. 4, 5 Tetraploid apomitic BRA-000591. 4a, 5a DAPI staining; $\mathbf{4 b}, \mathbf{d}$ three pairs of $5 \mathrm{~S}$ rDNA sites; $\mathbf{4 c}, \mathbf{b}, \mathbf{5 b}$ two pairs of $18 \mathrm{~S}-5.8 \mathrm{~S}-25 \mathrm{~S}$ rDNA sites. In $\mathbf{5 a}, \mathbf{b}$ the chromosome pair with secondary constriction is marked with short arrows, the other pair with long arrows. Bars $5 \mu \mathrm{m}$

\section{References}

Araujo ACG, Nóbrega JM, Pozzobon MT, Carneiro VTC (2005) Evidence of sexuality in induced tetraploids of Brachiaria brizantha (Poaceae). Euphytica 144:39-50

Asker SE, Jerling L (1992) Apomixis in plants. CRC Press, Boca Raton

Basappa GP, Muniyamma M, Chinnappa CC (1987) An investigation of chromosome numbers in the genus Brachiaria (Poaceae: Paniceae) in relation to morphology and taxonomy. Can J Bot 65:2297-2309

Bernini CJ (1997) Análise citogenética e diferenciação cromossômica em espécies do gênero Brachiaria Grisebach. University of Londrina, Londrina-PR

Bernini C, Marin-Morales MA (2001) Karyotype analysis in Brachiaria (Poaceae) species. Cytobios 104:157-171

Boldrini KR, Pagliarini MS, CBd Valle (2006) Abnormal timing of cytokinesis in microsporogenesis in Brachiaria humidicola (Poaceae: Paniceae). J Genet 85:225-228 
Carman JG (1997) Asynchronous expression of duplicate genes in angiosperms may cause apomixis, bispory, tetraspory, and polyembryony. Biolog J Linnean Soc 61:51-94

Carman JG (2001) The gene effect: genome collisions and apomixis. In: Savidan Y, Carman JG, Dresselhaus T (eds) The flowering of apomixis: from mechanisms to genetic engineering. CIMMYT. IRS, Eur Comm, Mexico, pp 95-110

Carman JG (2007) Do duplicate genes cause apomixis? In: Hörandl E, Grossniklaus U, van Dijk PJ, Sharbel T (eds) Apomixis: evolution, mechanisms and perspectives. A.R.G. Gantner Verlag, Rugell, Liechtenstein, pp 63-92

Carnahan HL, Hill HD (1961) Apomixis in the Gramineae: Panicoideae. Am J Bot 54:253-263

Christopher J, Abrahan A (1976) Studies on the cytology and phylogeny of south Indian grasses. III. Subfamily V, Panicoidea; tribe (i) the Paniceae. Cytologia 41:621-637

Dujardin M (1979) Additional chromosome numbers and meiotic behavior in tropical African grasses from western Zaire. Can J Bot 57:864-876

Feulgen R, Rossenbeck H (1924) Mikroskopisch-chemischer Nachweis einer Nucleinsäure vom Typus der Thymonucleinsäure und die darauf beruhende elektive Färbung von Zellkernen in mikoskopischen Präparaten. Z Physiol Chem 135:203-248

Fransz P, Armstrong S, Alonso-Blanco C, Fischer TC, Torres-Ruiz RA, Jones G (1998) Cytogenetics for the model system Arabidopsis thaliana. Plant J 13:867-876

Gerlach WL, Bedbrook JR (1979) Cloning and characterization of ribosomal RNA genes from wheat and barley. Nucleic Acids Res 7:1869-1885

Gerlach WL, Dyer TA (1980) Sequence organization of the repeating units in the nucleus of wheat which contains 5S rRNA genes. Nucleic Acids Res 8:4851-4865

Gobbe J, Swenne A, Louant B-P (1981) Diploïdes naturels et autotetraploïdes induits chez Brachiaria ruziziensis Germain et Evrard: critères d'identification. Agro Topic 36:339-346

Gobbe J, Longly B, Louant BP (1982) Calendrier des sporogénèse et gametogénèse femelles chez le diploïde et le tetraploïde induit de Brachiaria rhuziziensis (Graminée). Can J Bot 60:2032-2037

Hanna WW, Bashaw EC (1987) Apomixis: its identification and use in plant breeding. Crop Sci 27:1136-1139

Karia CT, Duarte JB, Araujo ACG (2006) Desenvolvimento de Cultivares do Gênero Brachiaria (trin.) Griseb. no Brasil. Documentos 163:57

Koltunow AM, Grossniklaus U (2003) Apomixis: a developmental perspective. Ann Rev Plant Biol 54:547-574

Levan A, Fredga K, Sandberg AA (1964) Nomenclature for centromeric position on chromosomes. Hereditas 52:201-220

Maluszynska J, Hasterok R (2005) Identification of individual chromosomes and parental genomes in Brassica juncea using GISH and FISH. Cytogen Gen Res 109:310-314

Mendes DV (2004) Avaliação citogenética de acessos de Brachiaria brizantha (Gramineae). Universidade Estadual de Maringá, Maringá-PR

Mendes DV, Boldrini KR, Mendes-Bonato AB, Pagliarini MS (2006) Cytological evidence of natural allopolyploidy in Brachiaria brizantha. Genet Mol Res 5:797-803

Mendes-Bonato AB, Filho RGJ, Pagliarini MS, Valle CBd, Penteado MIO (2002a) Unusual cytological patterns of microsporogenesis in Brachiaria decumbens: abnormalities in spindle and defective cytokinesis causing precocious cellularization. Cell Biol Intern 26:641-646

Mendes-Bonato AB, Pagliarini MS, Forli F, Valle CBdo, Penteado MIO (2002b) Chromosome numbers and karyotype in Brachiaria brizantha (Gramineae). Euphytica 125:419-425
Mendes-Bonato AB, Risso-Pascotto C, Pagliarini MS, Valle CB (2006) Chromosome number and meiotic behaviour in Brachiaria jubata (Gramineae). J Genet 85:83-88

Miles JW, Escandon ML (1997) Further evidence on the inheritance of reproductive mode in Brachiaria. Can J Plant Sci 77:105-107

Nogler GA (1984) Genetics of apospory in apomictic Ranunculus auricomus V. Conclusions Botanica Helvetica 94:411-422

Penteado MIO, Santos ACM, Rodrigues IF, Valle CBdo, Seixas MAC, Esteves A (2000) Determinação de ploidia e avaliação da quantidade de DNA total em diferentes espécies do gênero Brachiaria. Boletim de Pesquisa 11. Embrapa Gado de Corte, Campo Grande, p 32

Pikaard CS (2000) Nucleolar dominance: uniparental gene silencing on a multi-megabase scale in genetic hybrids. Plant Mol Biol 43:163-177

Risso-Pascotto C, Pagliarini MS, Valle CBdo, Mendes-Bonato AB (2003) Chromosome number and microsporogenesis in pentaploid accession of Brachiaria brizantha (Gramineae). Plant Breed 122:136-140

Risso-Pascotto C, Pagliarini MS, Valle CBdo (2005) Multiple spindles and cellularization during microsporogenesis in an artificially induced tetraploid acession of Brachiaria ruziziensis (Gramineae). Plant Cell Rep 23:522-527

Schwarzacher T, Heslop-Harrison JS (2000) Practical in situ hybridization. Springer-Verlag, New York

Seijo JG, Lavia GI, Fernandez A, Krapovickas A, Ducasse D, Moscone EA (2004) Physical mapping of the 5S and 18S-25S rRNA genes by fish as evidence that Arachis duranensis and A. ipaensis are the wild diploid progenitors of A. hypogaea (Leguminosae). Am J Bot 91:1294-1303

Sotomayor-Ríos A, Velez-Fortuno J, Woodbury R, Schertz KF, Sierra-Bracero A (1968) Description and cytology of a form of Signalgrass (Brachiaria brizantha Stapf.) and its agronomic behavior compared to Guineagrass (Panicum maximum Jack.). J Agric University PR 44:208-220

Swenne A, Louant B, Dujardin M (1981) Induction par la colchicine de formes autotetraploïdes chez Brachiaria ruziziensis Germain et Evrard (Graminée). Agro Tropic 36:134-141

Thompson RA, Estes JR (1986) Anthecial and foliar micromorphology and foliar anatomy of Brachiaria (Poaceae: Paniceae). Am J Bot 3:398-408

Tucker MA, Koltunow AMG (2009) Sexual and asexual (apomictic) seed development in flowering plants: molecular, morphological and evolutionary relationships. Funct Plant Biol 36:490-504

Utsunomiya KS, Pagliarini MS, Valle CBdo (2005) Microsporogenesis in tetraploid accessions of Brachiaria nigropedata (Ficalho $\&$ Hiern) Stapf (Gramineae). Biocell 29:295-301

Valle CBdo, Bitencourt GA, Chiari L, Resende RMS, Jank L, Arce A (2008) Identification of the mode of reproduction in Brachiaria humidicola hybrids. In: XX International Congress on Sexual Plant Reproduction. Documentos 259, Embrapa Brasilia, p 197

Valle CBdo, Glienke C (1991) New sexual accessions in Brachiaria. Apo News 3:11-13

Valle CBdo, Savidan Y (1996) Genetics, cytogenetics and reproductive biology of Brachiaria. In: Miles JW, Maass BL, Valle CBdo (eds) Brachiaria: biology, agronomy and improvement. CIATEMBRAPA, Cali-Colombia, p 288

Valle CBdo, Glienke C, Leguisamon GOC (1994) Inheritance of apomixis in Brachiaria, a tropical forage grass. Apo News $7: 42-43$ 